\title{
STUDIES IN EXHAUSTION
}

\section{AN EXPERIMENTAL RESEARCH}

\author{
G. W. CRILE \\ CLEVELAND
}

\section{INTRODUCTION}

The first purpose of this research has been to identify the organs and tissues which are affected by the various causes of exhaustion. It is at once obvious that these do not include the skin, the tendons, the connective tissue, the fat, the bones, the cartilage, the teeth, the hair, the organs of the digestive system or of the genito-urinary system, the lymphatic vessels or glands, the spleen, the sweat glands, the pancreas or the organs of common sensation. The organs and tissues in which one would expect to find signs of exhaustion are organs that are essential to life within the period of death from acute exhaustion.

The second purpose has been to ascertain whether or not all the known causes of exhaustion produce identical end-effects in the essential organs. That is to say, do insomnia, infection, exertion, emotion, asphyxia, exophthalmic goiter, iodism, anesthesia, the excision of organs, hemorrhage, etc., cause similar and identical changes in certain vital organs? The expectation that such an identity of change might be found was based on the identity of the essential symptoms of exhaustion-mental and physical prostration, rapid pulse, rapid respiration, falling blood pressure, sweating, etc.

The expectation that the physical changes might be identical was also based on the fact that whatever the cause of exhaustion, stimulants are of no value; that the period of time required for ultimate restoration is much the same; that want of sleep intensifies the degree of exhaustion; that sleep accelerates repair-is essential for ultimate restoration. In other words, in these researches, we have physical evidence of the identity of the lesions in exhaustion, no less than of the identity of the condition whereby restoration is achieved. This physical evidence embraces changes in histologic structure, changes in the hydrogen-ion concentration of the blood; changes in reserve alkalinity; progressive changes in the temperature and in the electric conductivity during the processes which lead to exhaustion. This evidence forms a foundation on which practical clinical methods are based. ${ }^{1}$

1. Throughout the prosecution of this research, an extensive study of the literature has been made by my collaborators and myself. Economy of space has forbidden the publication of an inclusive list. It should be added, moreover, that an adequate survey of the mass of literature in many languages which has been promulgated by the workers in the various fields with which these studies have been concerned would be a large research in itself. 


\section{Insomnia}

In 1900, during an investigation into the cause of shock, I first became convinced that in shock the brain cells must show morphologic changes. A histologic study of the brains of animals after traumatic and emotional shock was therefore undertaken in my laboratory, in collaboration with Dr. D. H. Dolley. ${ }^{2}$ These histologic studies were later extended, in collaboration with Drs. J. B. Austin and F. W. Hitchings, to include exhaustion from many other causes, such as exertion, infection, foreign protein reaction, acids, drug stimulants, excision of organs and activating secretions. ${ }^{3}$ The identical effects produced in each instance on the histologic structure of the brain, the suprarenals and the liver, and the fact that in none of these studies could the primary cause of exhaustion be completely isolated, nor was it possible to determine exactly what fraction of the end-result was due to each contributing factor, led us to undertake an investigation of the exhaustion produced by the most normal type of energy transformation, involving neither an excessive drive nor any pathologic influence, namely, the exhaustion due to prolonged consciousness, or insomnia.

Since into the average normal conscious state enter various factors, such as muscular exertion, emotion and "mental work," it follows that these factors represent merely varying degrees of intensity of the colorless consciousness which runs along the quiescent border of sleep. Therefore, the organism may do as much work of an identical kind in a tense quarter of an hour of such concentrated consciousness, as is represented by a violent muscular exertion or an overwhelming emotion, as is done in several days of droning consciousness.

But if droning consciousness with its slower rate of energy transformation is continued long enough, without even a moment of restor. ing sleep, then a degree of exhaustion would be reached as profound as that produced by the drive of a violent muscular struggle, of an intense emotion, of physical injury, of infection, etc., and the histologic lesions wrought by insomnia would be identical with those wrought by exertion, emotion, infection, etc. Moreover, it would follow, that, if an animal is partially exhausted by insomnia, its complete exhaustion or death could be caused by less exertion, less emotion, less injury, less infection than would exhaust or kill a normal animal.

2. Dolley, D. H.: J. A. M. A. 68:756-757, 1917; J. M. Research 34:305-323, 1916; ibid. 22:331-378, 1910; ibid. 24:309-343, 1911 ; ibid. 21:95-113. 1909. Dolley, D. H., and Crile, G. W. : J. M. Research 20:275-295, 1909.

3. Crile, G. W.: Proc. Soc. Exper. Biol. \& Med. 7:87-88, 1909-1910; Tr. Am. Surg. A. 28:553-559, 1910. Hitchings, F. W.: J. Exper. Med. 20:595$598,1914$. 


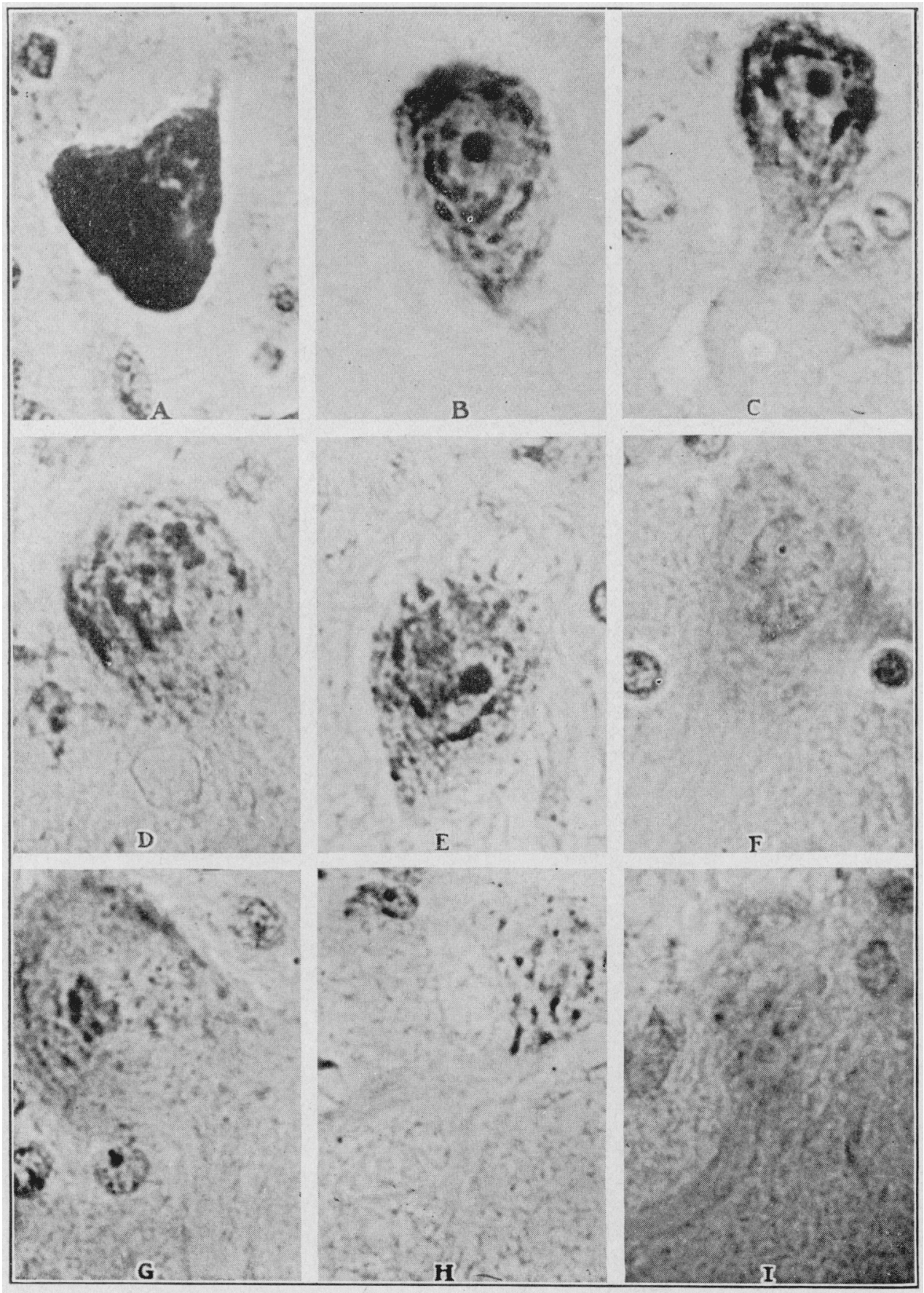

Figure 1 
Fig. 1.-Classification of brain cells, showing progressive stages of exhaustion: $A$, Stage 1: The so-called hyperchromatic stage. The changes consist essentially in an increase in the chromatic material, both diffuse and in formed masses. The increase is not confined to the cytoplasm but occurs also in the nucleoplasm. $B$, Stage 2: The normal average amount of chromatin is present in the cell body, but it is beginning to disappear from the dendrite. Except for the latter change, this represents the practically normal cell. $C$, Stage 3: There is well marked disappearance of the chromatin. The tendency of that which remains is to collect peripherally in both the cytoplasm and the nucleoplasm. The cell and the nucleolus are somewhat swollen. $D$, Stage 4: The chromatin has almost entirely disappeared from the cytoplasm, which is beginning to show signs of disintegration. $E$, Stage 5: Except in the nucleolus, there is no chromatin inside the nucleus, and very little outside. Vacuolization and disintegration of the cytoplasm are very apparent. $F$, Stage 6: The chromatin in the nucleolus is all that is left. The nucleoplasm is vacuolated. $G$, Stage 7: The chromatin in the nucleolus is passing out into the cytoplasm. The nucleoplasm is still further degenerated. $H$, Stage 8 . The process of disintegration is carried still further. $I$, Stage 9: The chromatin has disappeared even from the nucleolus. The nuclear membrane has almost disappeared. The cell membrane is extensively ruptured. The cell is dead. 
Likewise, if the lesions in the brain, the liver and the suprarenals, which are produced by insomnia, are an index of the loss of physical power, and if the only normal antithesis of consciousness is sleep, then we should find that the histologic lesions of emotion, exertion and injury, like the lesions of insomnia, can be repaired only during sleep. Further, if reconstruction of the cells of the brain, the liver and the suprarenals occurs only during sleep, can a similar cellular reconstruction be accomplished by artificially produced states which resemble sleep? Is it possible to induce by artificial means a state in which restoration is effected without loss of consciousness in sleep-a state in which the respiration and pulse are slower, the body temperature diminished, histologic changes in the brain, the liver and the suprarenals are in part at least repaired and the body energy is in part at least restored?

If there is an artificially induced state in which these results are achieved, then, conversely, in a man or animal in that state, injury or infection would produce slighter histologic changes in the brain, the liver and the suprarenals, would cause less alteration of the pulse, temperature and respiration, and consequently should produce a slighter degree of exhaustion.

To test these hypotheses, our researches have included not only early and late histologic, biochemical, physical and clinical studies of animals subjected to varying degrees of insomnia, but also the effects of varying periods of sleep on the resultant lesions. We compared the restorative effects of sleep with those of substitutes for normal sleep, such as morphin and nitrous oxid. The study of diurnal sleep naturally suggested the study of seasonal sleep, and we added to our research histologic examinations of hibernating animals, before, during and after the period of hibernation.

Since every manifestation of energy transformation is in the final analysis but a more or less intensified consciousness, studies of normal consciousness and of sleep give the least complicated picture of the mechanism by which energy is transformed, as well as the most fundamental criterion for the study of all forms of intensified consciousness.

\section{A. Histologic STUDIES}

Strong, healthy rabbits were chosen as the subjects of these experiments. They were kept awake by relays of medical students for periods ranging from 96 to 118 hours. They were given abundant food and water and were subject to the least disturbance that would suffice to keep them awake. Thus they existed without exercise, injury, infection or apparent emotion-but writhout sleep. 
The Brain Cells.-The charts show the results obtained by plotting individual differential Purkinje cell counts ${ }^{4}$ from seven rabbits in each of two series of experiments, in one series the recovery period being nine and one-half days, in the other sixteen days. A period of more than a year intervened between these two series of experiments; the differential counts were made at irregular intervals, and until the data were all in hand what its graphic expression would show was known to nobody (Fig. 2).

Table 1.-Differential Purkinje Cell Counts: Normal Standard FOR RABBITS *

\begin{tabular}{|c|c|c|c|c|c|c|c|c|c|}
\hline & Active & \multicolumn{4}{|c|}{ Fatigued } & \multicolumn{4}{|c|}{ Fxhausted } \\
\hline & $\begin{array}{cc}\text { Stage } & \text { Stage } \\
\text { I } & \text { II }\end{array}$ & $\begin{array}{l}\text { Stage } \\
\text { III }\end{array}$ & Stage & $\underset{V}{\text { Stage }}$ & $\begin{array}{c}\text { Stage } \\
\text { VI }\end{array}$ & $\begin{array}{c}\text { Stage } \\
\text { VIII }\end{array}$ & $\begin{array}{l}\text { Stage } \\
\text { VIII }\end{array}$ & $\begin{array}{l}\text { Stage } \\
\text { IX }\end{array}$ & $\underset{\mathrm{X}}{\mathrm{Stage}}$ \\
\hline Normal Rabbit 1.... & $\underbrace{30}, 32$ & 26 & 8 & 4 & 0 & 0 & 0 & 0 & 0 \\
\hline $\begin{array}{c}\text { Normal Rabbit } 2 \ldots \\
\text { Grouned }\end{array}$ & $27-21 \%$ & 12 & 9 & 4 & 4 & 0 & 0 & 0 & 0 \\
\hline Normal Rabbit $3 . .$. & $16 \quad 48$ & 21 & 11 & 3 & 1 & 0 & 0 & 0 & 0 \\
\hline Normal Rabbit 4..... & 29 & $\underbrace{19}$ & 13 & 6 & 0 & 0 & 1 & 0 & 0 \\
\hline Normal Rabbit $5 . .$. & $2 9 \longdiv { 3 5 }$ & 20 & 8 & 4 & 3 & 0 & 1 & 0 & 0 \\
\hline Gormal Rabbit $6 . .$. & $25 \quad 40$ & 15 & 6 & 6 & 6 & 2 & 0 & 0 & 0 \\
\hline $\begin{array}{r}\text { Grouped........ } \\
\text { Normal Rabbit } 7 . . .\end{array}$ & 35 & 22 & 4 & 5 & 2 & 0 & 2 & 0 & 0 \\
\hline Normal Rabbit 8.... & $41.68 \%$ & 18 & 7 & 4 & 3 & 0 & 0 & 0 & 0 \\
\hline Normal Rabbit $9 . .$. & $37 \quad 29$ & 19 & 6 & 6 & 3 & 0 & 0 & 0 & 0 \\
\hline $\begin{array}{l}\text { Grouped } \\
\text { Normal Rabbit 10..... } \\
\text { Grouped............... }\end{array}$ & $\underbrace{29}_{-62 \%}$ & 23 & $7^{34}$ & 4 & 3 & 0 & 1 & 0 & 0 \\
\hline Group a verage........ & $64.8 \%$ & & 34. & $5 \%$ & & & 0.7 & $\%$ & \\
\hline
\end{tabular}

* In this table and in Tables 2 and 3, the figures are derived from the careful study of 2,000 cells that were actually counted and of many more that were rejected because they had been cut through the nucleolus and axon.

It should be stated here that in general our experiments have shown that any activation produces nerve cell changes throughout the central nervous system, these changes being most marked in the cortex, less in the cerebellum and clearly demonstrable in the medulla and the cord. As the changes in the Purkinje cells closely parallel those in the cortical and other nerve cells, and as the Purkinje cells by reason of their distinctive size and shape most graphically portray the various stages of stimulation and exhaustion, they were used in making the differential cell counts described herewith, and we shall employ them for illustrative purposes throughout this discussion (Figs. 3 and 4).

4. Since accurate observations depended on the establishment of a standard of cell classification, a method of making differential cell counts was devised by $\mathrm{Dr}$. Hitchings, and the arbitrary classification shown in Figure 1 was adopted by Dr. Dolley and Dr. Austin. 
It will be seen that the period before the maximum increase and maximum decrease in the number of the active and fatigued cells, respectively, differed in the two series, in one being nine days and in the other three days. This difference is undoubtedly due to the fact that, owing to a combination of minor factors, the rabbits in one series
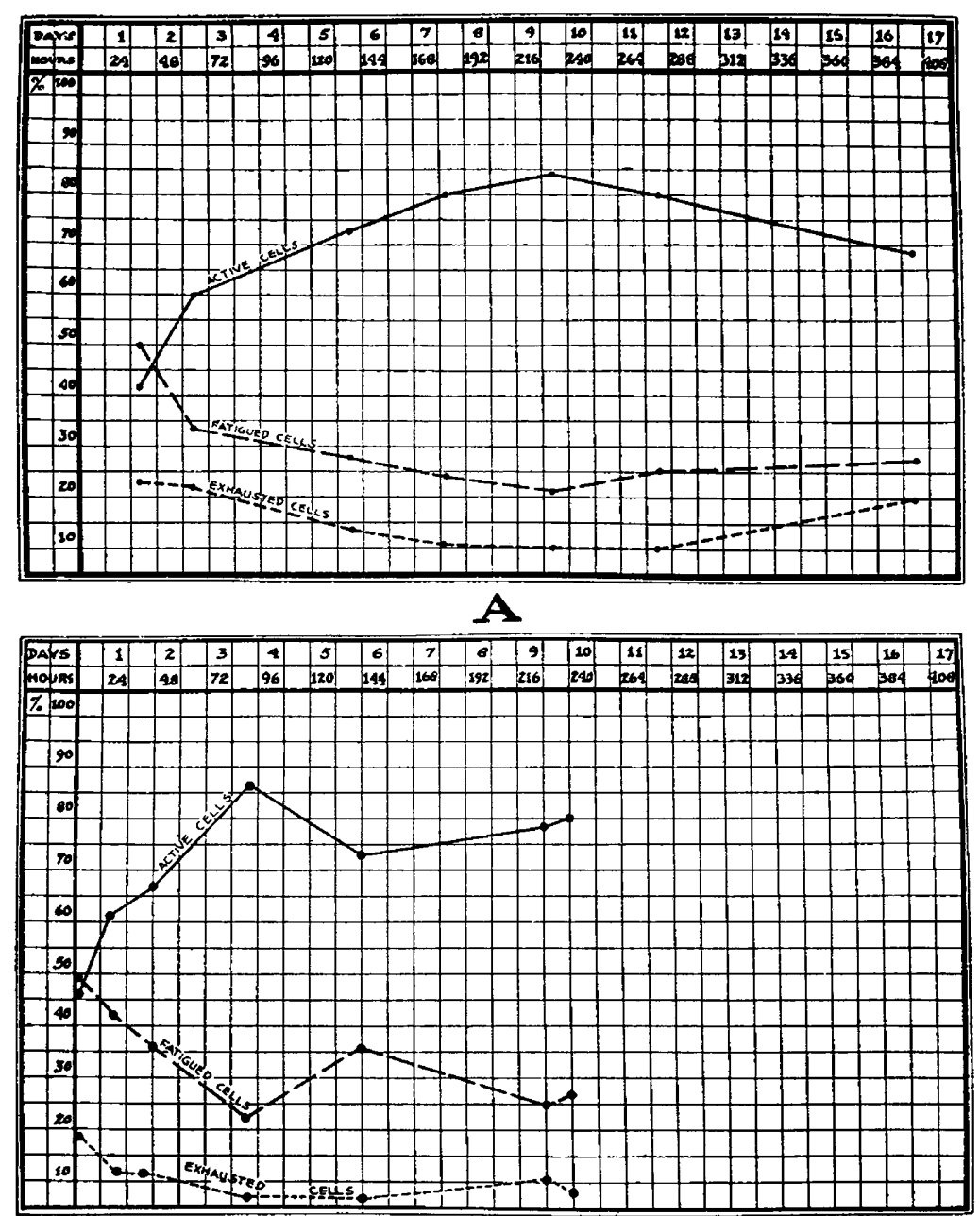

B

Fig. 2.-Progressive changes in the differential Purkinje cell count during recovery from insomnia.

were more affected than those in the other series. The corresponding difference in clinical behavior bears out this assumption.

It will also be seen that the maximum increase of the active cells is considerably above the average of 64.8 per cent. found in normal 
rabbits (Table 1), so that there was apparently a period of oacreaction (hyperchromatisn).

In both series, the percentage of exhausted cells begins to increase again after the period of maximum reaction. In one series, every rabbit not killed by this time died soon after of a cause unexplained even after careful necropsies. We concluded, therefore, that the original "dose" of insomn:a was really a fatal one, and that the apparently favorable reaction was only temporary, death doubtless being due to the fact that the brain cell destruction increased again until a nonsurvivable limit

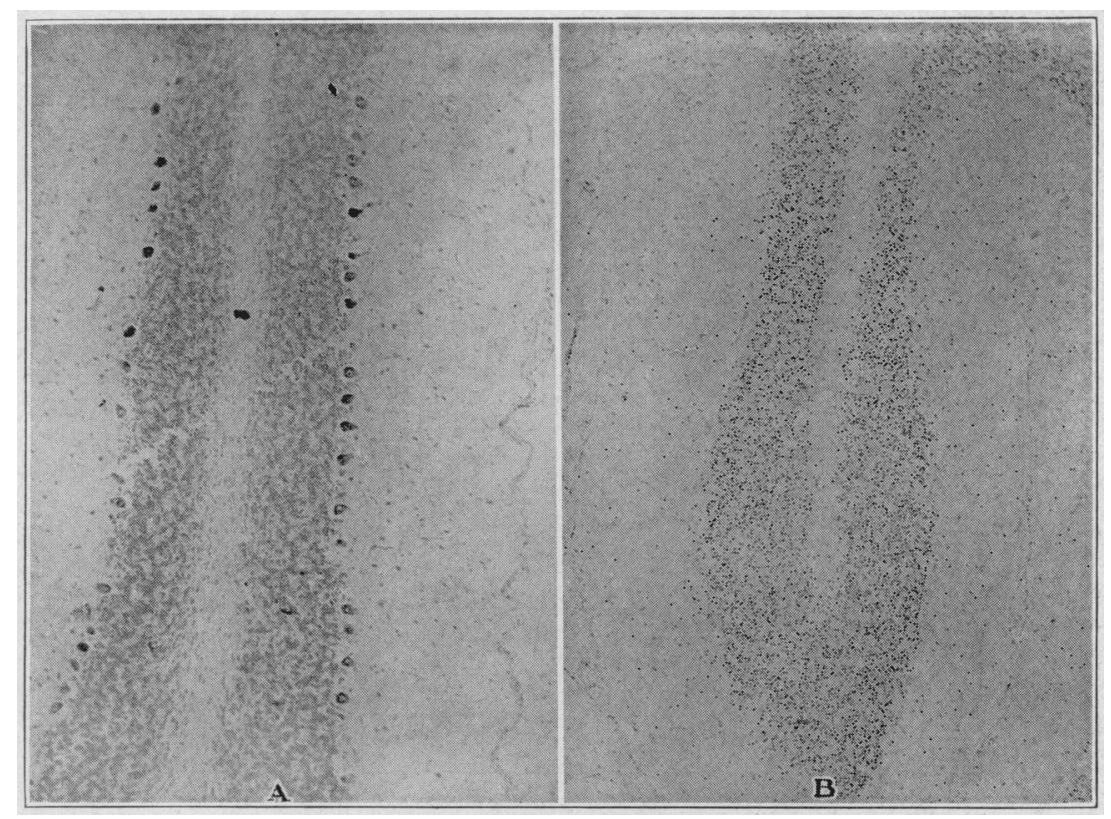

Fig. 3.-Changes in the Purkinje cells of the cerebellum produced by long insomnia: $A$, section of normal cerebellum of rabbit; $B$, section of cerebellum of rabbit after insomnia of one hundred and nine hours' duration. The well stained, clearly defined Purkinje cells in $A$ may be compared with the faint traces of the Purkinje cells which are barely visible in $B . \times 100$.

had been reached. It is probable that no individual, man or animal, can survive the loss of 15 per cent. of his brain cells.

The Lizer.-In observations on the livers from a series in which animals were killed at varying times after prolonged insomnia, the liver was found to be markedly altered five times, moderately altered once, and normal twice. In other words, it was more or less affected in six out of eight experiments.

The changes were most distinct near the peripheries of the lobules, and not only were the cell contents affected, but the cell walls also. 
The nuclei were often eccentric, sometimes distorted in shape and in many instances had disappeared entirely. The granules were diminished in number or had practically disappeared in many cells. There were vacuoles in many cells. The most striking change, however, was the marked swelling of the cells as a whole. In many cells, this was so extreme that it obliterated the normal linear arrangement of the cells and occluded the lymph and venous spaces between the rows (Figs. 5 and 6$)$.

Table 2.-Changes in the Liver After Varying Periods of Recovery FROM PROLONGED INSOMNIA

\begin{tabular}{|c|c|}
\hline $\begin{array}{l}\text { Time of Recovery } \\
\text { After Insomnia }\end{array}$ & Effect on Liver \\
\hline $\begin{array}{l}\text { Immediately after } \\
\text { Immediately after } \\
181 / 2 \text { hours } \\
361 / 2 \text { hours } \\
681 / 2 \text { hours } \\
51 / 2 \text { days } \\
9 \text { days } \\
91 / 2 \text { days } \\
121 / 2 \text { days }\end{array}$ & $\begin{array}{l}\text { Markedly altered } \\
\text { Markedly altered } \\
\text { Normal } \\
\text { Markedly altered } \\
\text { Markedly altered } \\
\text { Slightly altered } \\
\text { Moderately altered } \\
\text { Normal } \\
\text { Markedly altered }\end{array}$ \\
\hline
\end{tabular}

Table 3.-Changes in the Suprarenals After Various Periods of Reconizi from Prolonged Insomnia

\begin{tabular}{|c|c|c|}
\hline $\begin{array}{l}\text { Time of Recovery } \\
\text { After Insomnia }\end{array}$ & Cortex & Medulla \\
\hline $\begin{array}{l}\text { Immediately after } \\
\text { Immediately after } \\
18^{1 / 2} \text { hours } \\
361 / 2 \text { hours } \\
681 / 2 \text { hours } \\
51 / 2 \text { days } \\
9 \text { days } \\
91 / 2 \text { days }\end{array}$ & $\begin{array}{l}\text { Markedly altered } \\
\text { Slightly altered } \\
\text { Normal } \\
\text { Slightly altered } \\
\text { Slightly altered } \\
\text { Normal } \\
\text { Slightly altered } \\
\text { Slightly altered }\end{array}$ & $\begin{array}{l}\text { Normal } \\
\text { Normal } \\
\text { Normal } \\
\text { Normal } \\
\text { Normal }\end{array}$ \\
\hline
\end{tabular}

In a few instances, especially prepared liver sections stained by Best's carmin method showed that in the cases in which much damage had been done to the liver there was a corresponding decrease in the glycogen content. Apparently, therefore, the organic changes were accompanied by loss of functional power, at least in this one particular. 
The Suprarcnals.-.-The histologic changes in the suprarenals can be grouped according to their occurrence in the medullary or the cortical portion. Those in the medullary portion were negligible, in five out of six observations the medulla being well stained and otherwise normal, while in the sixth case there was but slight alterations. As for the cortex, on the other hand, in eight cases, six cortices showed alteration, while two were normal. In the former, not only were the ce'l contents affected, but in many instances the cell walls themselves. Many of the nuclei were irregular in shape and eccentric, while in some cells the nuclei had disappeared. The cytoplasm was frequently vacuolated, and

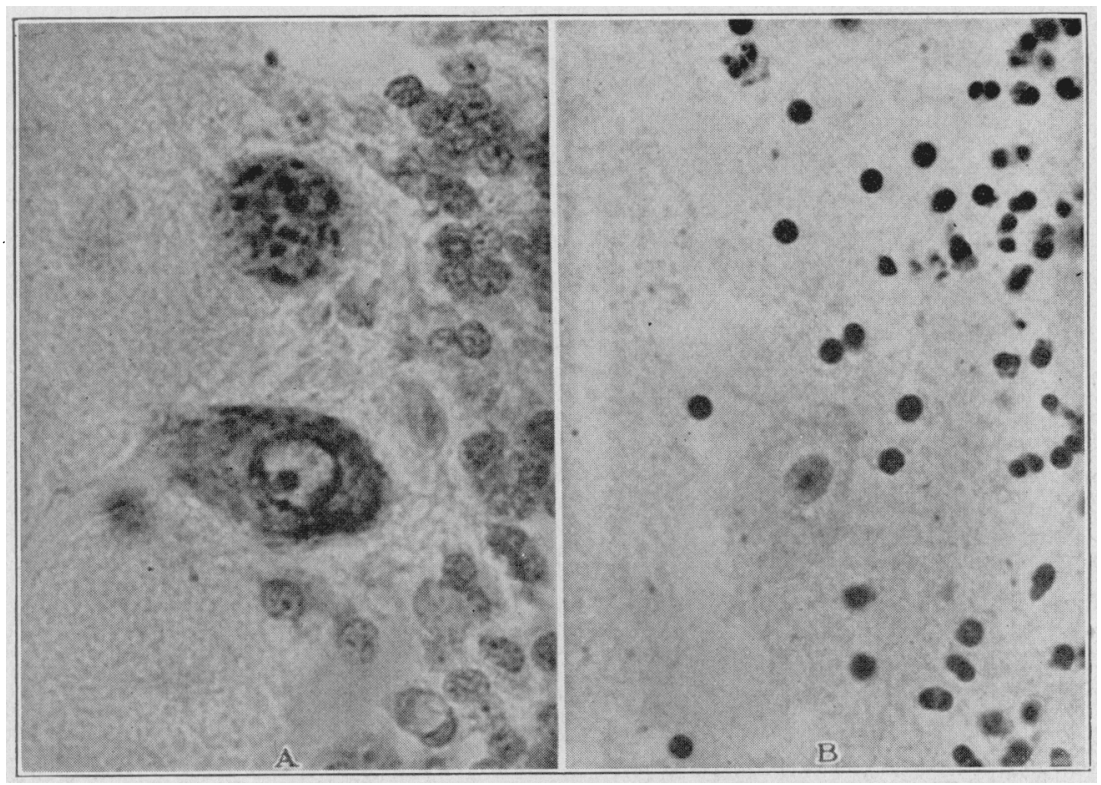

Fig. 4.-Changes in the Purkinje cells of the cerebellum produced by prolonged insomnia: $A$, section of normal cerebellum of rabbit; $B$, section of cerebellum of rabbit after insomnia of one hundred and nine hours' duration. $\times 1600$. In $A$ may be noted the clearly defined outline, the well defined nucleus and general distribution of the chromatin in the Purkinje cell, indicating that the cell is in a normally active stage. Contrast this with $B$, noting the disappearance of the cell membrane, chromatolysis, and the faint mucleus and nucleolus in the only Purkinje cell.

in many cells the walls were ruptured, often in several places (Figs. 7 and 8). We can offer no explanation for the localization of the histologic changes in the cortex, rather than in the medulla, of the suprarenals.

The Thyroid.-In five observations on the thyroid, nothing abnormal was found. The colloid material raried in amount in individual 
experiments, but was neither particularly increased nor diminished. In certain instances, there was an increase in the interstitial connective tissue. There was no consistent tendency toward any kind of structural change.

The Pancreas.-Five observations on the pancreas were as negative as those on the thyroid.

The Kidneys.-In six out of seven observations, the kidneys were normal. In the one exception the alteration was slight.

Table 4.--Histclcgic Changes Produced by Insomnia

\begin{tabular}{|c|c|c|c|c|c|c|}
\hline $\begin{array}{c}\text { Exp. } \\
\text { No. }\end{array}$ & Animal & Aetivator & $\begin{array}{l}\text { Duration } \\
\text { of Activa- } \\
\text { tion }\end{array}$ & $\begin{array}{cc}\text { Brain Cells, } \\
\text { Condi- } \\
\text { tion } & \text { Cent. }\end{array}$ & Suprarenals & Liver \\
\hline 5 & Rabbit & Insomnia & $\begin{array}{l}96 \text { hours; } \\
\text { killed im- } \\
\text { mediately }\end{array}$ & $\begin{array}{l}\text { Active......51 } \\
\text { Fatigued...35 } \\
\text { Exhausted..14 }\end{array}$ & $\begin{array}{l}\text { Cortex: great loss } \\
\text { of ey toplas m } \\
\text { and vacuolation. } \\
\text { Medulla: affected } \\
\text { but not so much } \\
\text { as cortex }\end{array}$ & $\begin{array}{l}\text { Condition b a d: } \\
\text { cytoplasm almost } \\
\text { gone: nuclei ec- } \\
\text { centric and not } \\
\text { well stained; cells } \\
\text { contained large } \\
\text { empty spaces }\end{array}$ \\
\hline 14 & Rabbit & Insomnia & 105 hours & $\begin{array}{l}\text { Active.....28 } \\
\text { Fatigued,.60 } \\
\text { Fxhausted..12 }\end{array}$ & $\begin{array}{l}\text { Cortex: marked } \\
\text { loss of cyto- } \\
\text { plasm and vacu- } \\
\text { olation through- } \\
\text { out }\end{array}$ & $\begin{array}{l}\text { Marked uniform } \\
\text { loss of cyto- } \\
\text { plasm through- } \\
\text { out; great dilata- } \\
\text { t io n of capil- } \\
\text { laries; stain pale }\end{array}$ \\
\hline 15 & Rabbit & Insomnia & 105 hours & $\begin{array}{l}\text { Active.....28 } \\
\text { Fatigued...53 } \\
\text { Fxhausted..19 }\end{array}$ & $\begin{array}{l}\text { Cortex: almost } \\
\text { normal; a few } \\
\text { celis showed } \\
\text { slight loss of } \\
\text { cytoplasm } \\
\text { Medulla: marked } \\
\text { los s of cyto- } \\
\text { plasm and vacu- } \\
\text { olation; nuelei } \\
\text { deeply stained; } \\
\text { cytoplasm very } \\
\text { lightly stained }\end{array}$ & $\begin{array}{l}\text { Normal; no loss of } \\
\text { cytoplasm }\end{array}$ \\
\hline 1 & Rabbit & Insomnia & 109 hours & $\begin{array}{l}\text { Active......53 } \\
\text { Fatigued...33 } \\
\text { Exhausted..14 }\end{array}$ & $\begin{array}{l}\text { Cortex: marked } \\
\text { loss of cyto- } \\
\text { plasm in outer } 1 / 3 \\
\text { of cortex; vac- } \\
\text { uolated }\end{array}$ & $\begin{array}{l}\text { Loss of cytoplasm } \\
\text { with small vacu- } \\
\text { oles in all cells, } \\
\text { but more marked } \\
\text { around periph- } \\
\text { ery of lobules }\end{array}$ \\
\hline 20 & Rabbit & Insomnia & 118 hours & $\begin{array}{l}\text { Active......42 } \\
\text { Fatigued...44 } \\
\text { Exhausted..14 }\end{array}$ & $\begin{array}{l}\text { Cortex: marked } \\
\text { los of of cyto- } \\
\text { plasm but with } \\
\text { somenormal cells } \\
\text { in rows } \\
\text { Medulla: normal }\end{array}$ & $\begin{array}{l}\text { All cells swollen, } \\
\text { vacuolated and } \\
\text { with gre at or } \\
\text { even total loss of } \\
\text { cytoplasm }\end{array}$ \\
\hline 27 & Rabbit & Insomnia & 118 hours & $\begin{array}{l}\text { Active......47 } \\
\text { Fatigued...28 } \\
\text { Exhausted..25 }\end{array}$ & $\begin{array}{l}\text { Cortex: most cells } \\
\text { normal; narrow } \\
\text { strip of outer } \\
\text { portion shows } \\
\text { slight loss of } \\
\text { cytoplasm } \\
\text { Medulla: normal }\end{array}$ & $\begin{array}{l}\text { Great Ioss of cyto- } \\
\text { plasm in all cells; } \\
\text { cells swollen, vac- } \\
\text { uolated, irregular } \\
\text { in outline with } \\
\text { eccentric nuclei }\end{array}$ \\
\hline
\end{tabular}

The Spleen.-In five observations the spleen was normal.

- The Stomach and Intestines.-In thirteen observations, unevenly distributed among the stomach and small and large intestines, no abnormal condition was found.

Restoration of the Cells Exhausted by Insomnia.-In order, if possible, to discover a clue to the manner in which cells exhausted from 
TABle 5.-Effect of Varying Periods of Recovery on the Histologic Changes Produced by Insomnia

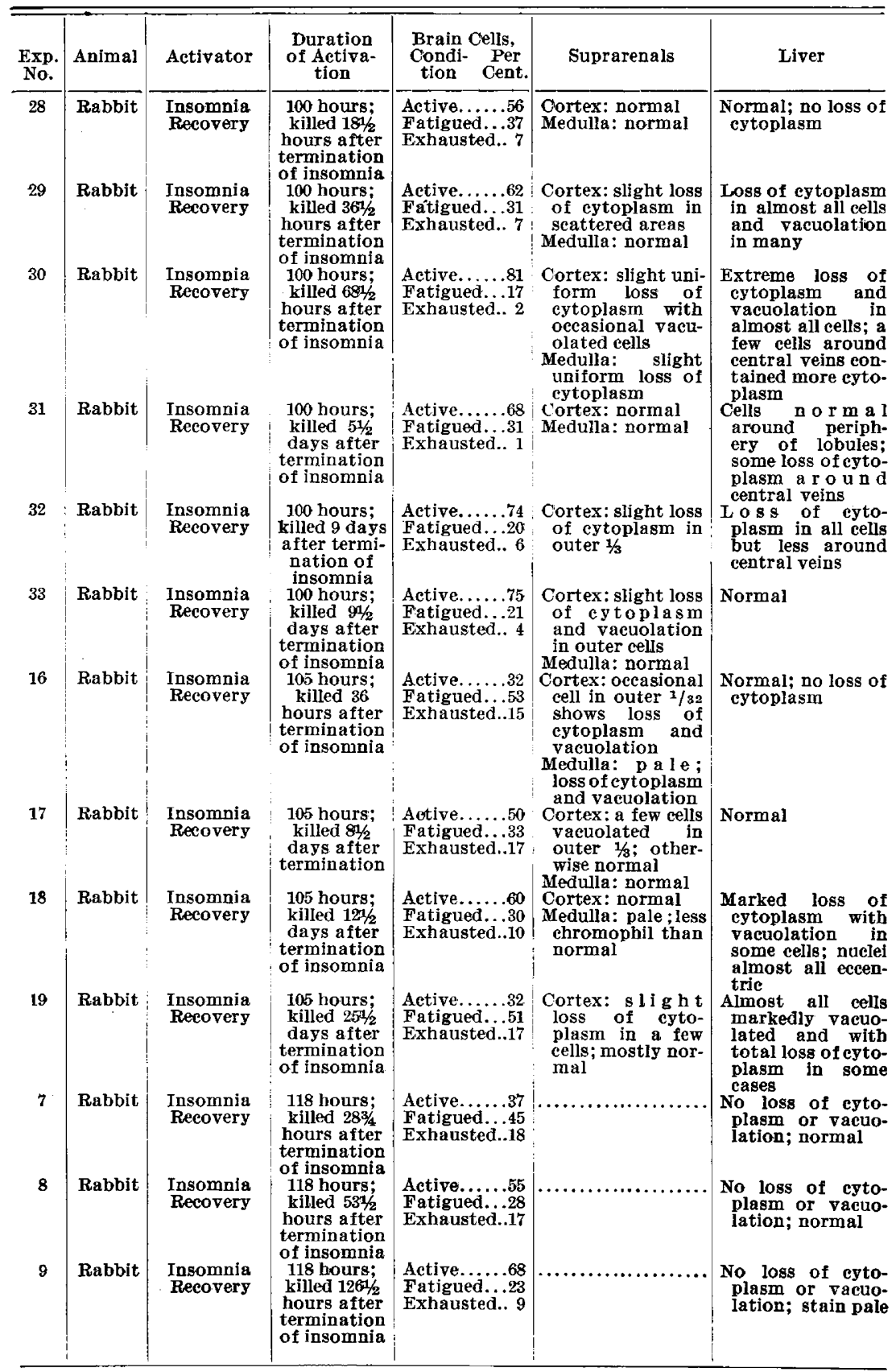


TABLE 5.-Effect of Varying Perions of Recovery on the Histologic Changes Produced by Insomnia-(Contimued)

\begin{tabular}{|c|c|c|c|c|c|c|}
\hline $\begin{array}{l}\text { Exp. } \\
\text { No. }\end{array}$ & Animal & Activator & $\begin{array}{l}\text { Duration } \\
\text { of Activa- } \\
\text { tion }\end{array}$ & 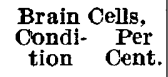 & Suprarenals & Liver \\
\hline 10 & Rabbit & $\begin{array}{l}\text { Insomnia } \\
\text { Recovery }\end{array}$ & $\begin{array}{l}118 \text { hours; } \\
\text { killed 1741/2 } \\
\text { hours after } \\
\text { termination } \\
\text { of insomnia }\end{array}$ & $\begin{array}{l}\text { Active......75 } \\
\text { Fatigued...19 } \\
\text { Exhausted.. } 6\end{array}$ & $\begin{array}{l}\text { Cortex: no loss of } \\
\text { cytoplasm or } \\
\text { vacuolation; } \\
\text { normal }\end{array}$ & $\begin{array}{l}\text { Large vacuoles } \\
\text { and loss of cyto- } \\
\text { plasm in extreme } \\
\text { periphery of lob- } \\
\text { ules only; other- } \\
\text { wise normal }\end{array}$ \\
\hline 11 & Rabbit & $\begin{array}{l}\text { Insomnia } \\
\text { Recovery }\end{array}$ & $\begin{array}{l}118 \text { hours; } \\
\text { killed } 222 \\
\text { hours after } \\
\text { termination } \\
\text { of insomnia }\end{array}$ & $\begin{array}{l}\text { Active......79 } \\
\text { Fatigued...16 } \\
\text { Exhausted.. }\end{array}$ & $\ldots$ & $\begin{array}{l}\text { M a r e d loss of } \\
\text { cytoplasm and } \\
\text { large vacuoles } \\
\text { present in the } \\
\text { lobules }\end{array}$ \\
\hline 12 & Rabbit & $\begin{array}{l}\text { Insomnia } \\
\text { Recovery }\end{array}$ & $\begin{array}{l}118 \text { hours; } \\
\text { killed } 2704 / 2 \\
\text { hours after } \\
\text { termination } \\
\text { of insomnia }\end{array}$ & $\begin{array}{l}\text { Active......75 } \\
\text { Fatigued...20 } \\
\text { Exhausted.. } 5\end{array}$ & $\begin{array}{l}\text { Cortex: normal } \\
\text { except for oeca- } \\
\text { sionalcell toward } \\
\text { periphery with } \\
\text { slight loss of } \\
\text { eytoplasm } \\
\text { Medulla: same as } \\
\text { cortex }\end{array}$ & \\
\hline $13^{*}$ & Rabbit & $\begin{array}{l}\text { Insomnia } \\
\text { Recovery }\end{array}$ & $\begin{array}{l}118 \text { hours; } \\
\text { killed } 390 \\
\text { hours after } \\
\text { termination } \\
\text { of insomnia }\end{array}$ & $\begin{array}{l}\text { Active......63 } \\
\text { Fatigued...22 } \\
\text { Exhausted..15 }\end{array}$ & $\ldots \ldots \ldots \ldots \ldots \ldots \ldots$ & $\begin{array}{l}\text { No loss of cyto- } \\
\text { plasm or vacuo- } \\
\text { lation }\end{array}$ \\
\hline
\end{tabular}

* The nuclei of many brain cells were very small, especially those in Stages 3 and 4 , inclusive.

TABle 6.-Effect of Sleep on the Histologic Changes Produced by Insomnia

\begin{tabular}{|c|c|c|c|c|c|c|}
\hline $\begin{array}{c}\text { Exp. } \\
\text { No. }\end{array}$ & Animal & Activator & $\begin{array}{l}\text { Duration } \\
\text { of Activa- } \\
\text { tion }\end{array}$ & $\underset{\text { Condi- }}{\text { Brain }} \underset{\text { Cent. }}{\text { Per }}$ & Suprarenals & Liver \\
\hline 6 & Rabbit & $\begin{array}{l}\text { Insomnia } \\
\text { Sleep }\end{array}$ & $\begin{array}{l}96 \text { hours; } \\
\text { killed after } \\
8 \text { hours } \\
\text { sleep }\end{array}$ & $\begin{array}{l}\text { Active......67 } \\
\text { Fatigued...21 } \\
\text { Exhausted..12 }\end{array}$ & $\begin{array}{l}\text { Cortex: slight loss } \\
\text { of cytoplasm } \\
\text { Medulla: about } \\
\text { normal }\end{array}$ & $\begin{array}{l}\text { Condition f a i ; } \\
\text { nucle } \text { p a I e, } \\
\text { shrunken only in } \\
\text { an occasional cell } \\
\text { in which there } \\
\text { was vacuolation } \\
\text { and the cyto- } \\
\text { plasm was dimin- } \\
\text { ished; in most } \\
\text { cells cytoplasm } \\
\text { dense and normal }\end{array}$ \\
\hline 2 & Rabbit & $\begin{array}{c}\text { Insomnia } \\
\text { Sleep }\end{array}$ & $\begin{array}{l}109 \text { hours; } \\
\text { killed after } \\
61 / 2 \text { hours } \\
\text { sleep }\end{array}$ & $\begin{array}{l}\text { Active.....68 } \\
\text { Fatigued...18 } \\
\text { Exhausted..14 }\end{array}$ & $\begin{array}{l}\text { Oortex: very } \\
\text { marked loss of } \\
\text { cytoplasm; large } \\
\text { vacuoles present }\end{array}$ & \\
\hline
\end{tabular}

any cause are restored, experiments were performed $(a)$ in which varying periods of recovery were allowed; $(b)$ in which a definite period of sleep was allowed immediately after the period of insomnia, the animal being killed at the end of the period of sleep; $(c)$ in which various agents were administered during the period of insomnia or at its termination. The results of these experiments are given in Tables $4,5,6,7$ and 8 . The restorative value of sleep is clearly shown, as is the efficiency of nitrous oxid-oxygen as a sleep substitute. 
TABle 7.-Effect of Nitrous Oxid-Oxygen Anesthesia on Histologic Changes Produced by Insomnia

\begin{tabular}{|c|c|c|c|c|c|c|}
\hline $\begin{array}{c}\text { Exp. } \\
\text { No. }\end{array}$ & Animal & Activator & $\begin{array}{l}\text { Duration } \\
\text { of Activa- } \\
\text { tion }\end{array}$ & $\underset{\text { Condi- }}{\text { Brain Cells, }} \underset{\text { Cent. }}{\text { Cer }}$ & Suprarenals & Liver \\
\hline 4 & Rabbit & $\begin{array}{l}\text { Insomnia; } \\
\text { intermittent } \\
\text { nitrous } \\
\text { oxid anes- } \\
\text { thesia }\end{array}$ & $\begin{array}{c}\text { 109 hours; } \\
\text { during this } \\
\text { period oxid } \\
\text { was given for } \\
\text { one hour out } \\
\text { of every six }\end{array}$ & $\begin{array}{l}\text { Active......94 } \\
\text { Fatigued... } 5 \\
\text { Exhausted.. } 1\end{array}$ & 0 & . \\
\hline 3 & Rabbit & $\begin{array}{l}\text { Insomnia; } \\
\text { continuous } \\
\text { nitrous } \\
\text { oxid anes- } \\
\text { thesia }\end{array}$ & $\begin{array}{c}109 \text { hours; } \\
\text { killed after } \\
61 / 2 \text { hours } \\
\text { sleep }\end{array}$ & $\begin{array}{l}\text { Active.....27 } \\
\text { Fatigued...46 } \\
\text { Exhausted..27 }\end{array}$ & $\begin{array}{l}\text { Cortex: slight loss } \\
\text { of cy toplas } \\
\text { and moderate } \\
\text { vacuolation of } \\
\text { some cells; occa- } \\
\text { sional cell totally } \\
\text { vacuolated } \\
\text { Medulla : slight } \\
\text { loss of cytoplasm } \\
\text { and vacuolation }\end{array}$ & $\begin{array}{l}\text { Most cells normal; } \\
\text { only slight loss } \\
\text { of cytoplasm in } \\
\text { an occasional cell }\end{array}$ \\
\hline
\end{tabular}

TABle 8.-Efrects of Various Agents on the Histologic Changes Produced by InSOMNia

\begin{tabular}{|c|c|c|c|c|c|c|}
\hline $\begin{array}{l}\text { Fixp. } \\
\text { No. }\end{array}$ & Ani- & Activator & $\begin{array}{c}\text { Duration } \\
\text { of Activa- } \\
\text { tion }\end{array}$ & 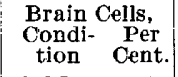 & Suprarenals & Liver \\
\hline 20 & $\underset{\text { bit }}{\text { Rab- }}$ & $\begin{array}{l}\text { Insomnia; no } \\
\text { sleep; epinephrin, } \\
1 / 1000, \text { m } \text { every } \\
4 \text { hours hypo- } \\
\text { dermically }\end{array}$ & 112 hours & $\begin{array}{l}\text { Active......22 } \\
\text { Fatigued...59 } \\
\text { Exhausted..19 }\end{array}$ & $\begin{array}{l}\text { Cortex: normal } \\
\text { Medulla: normal }\end{array}$ & $\begin{array}{l}\text { Cells around cen- } \\
\text { tral vein normal: } \\
\text { all others greatly } \\
\text { vacuolated and } \\
\text { w it h eccentric } \\
\text { nuclei }\end{array}$ \\
\hline 21 & $\underset{\text { bit }}{\text { Rab- }}$ & $\begin{array}{l}\text { Insomnia; no } \\
\text { sleep; sodium } \\
\text { bicarbonate, } \\
\text { 10 c.c. saturated } \\
\text { solution by rec- } \\
\text { tum twice a day }\end{array}$ & 112 hours & $\begin{array}{l}\text { Active......48 } \\
\text { Fatigued...38 } \\
\text { Exhausted..14 }\end{array}$ & $\begin{array}{l}\text { Cortex: normal } \\
\text { Medulla: normal }\end{array}$ & $\begin{array}{l}\text { Great Ioss of cyto- } \\
\text { plasm; all cells } \\
\text { vacuolated, nuclei } \\
\text { large, well stained } \\
\text { eccentric }\end{array}$ \\
\hline 22 & $\begin{array}{c}\text { Rab- } \\
\text { bit }\end{array}$ & $\begin{array}{l}\text { Insomnia; no } \\
\text { sleep; dextrose } \\
10 \text { e.c. } 2 \% \text { solu- } \\
\text { tion by rectum, } \\
\text { twice a day }\end{array}$ & 112 hours & $\begin{array}{l}\text { Aetive......35 } \\
\text { Fatigued...49 } \\
\text { Exhausted..16 }\end{array}$ & $\begin{array}{l}\text { Cortex: slight loss } \\
\text { of ey toplasm } \\
\text { throughout but } \\
\text { more marked } \\
\text { peripherally } \\
\text { Medulla: normal }\end{array}$ & $\begin{array}{l}\text { Marked loss of } \\
\text { cytoplasm in per- } \\
\text { ipheral cel's of } \\
\text { lobules with vac- } \\
\text { uolation in some } \\
\text { cells; cells around } \\
\text { central veins nor- } \\
\text { mal* }\end{array}$ \\
\hline 23 & $\begin{array}{c}\text { Rab- } \\
\text { bit }\end{array}$ & $\begin{array}{c}\text { Insomnia; no } \\
\text { sleep; sodium } \\
\text { bic arbonate } \\
\text { saturated solu- } \\
\text { tion } 5 \text { c.c. and } \\
\text { dextrose } 2 \% \text { solu- } \\
\text { tion } 10 \text { c.c. by } \\
\text { rectum twice } \\
\text { dajly; also epi- } \\
\text { nephin mV every } \\
4 \text { hours }\end{array}$ & 112 hours & $\begin{array}{l}\text { Active......38 } \\
\text { Fatigued...46 } \\
\text { Exhausted..16 }\end{array}$ & $\begin{array}{l}\text { Cortex : general } \\
\text { loss of eyto- } \\
\text { plasm; no vac- } \\
\text { uolation } \\
\text { Medulla: normal }\end{array}$ & $\begin{array}{l}\text { In most cells only } \\
\text { slight loss of } \\
\text { eytoplasm but in } \\
\text { some around the } \\
\text { periphery of the } \\
\text { lobules there was } \\
\text { marked loss }\end{array}$ \\
\hline 24 & $\underset{\text { bit }}{\text { Rab-i }}$ & $\begin{array}{l}\text { Insomnia; no } \\
\text { sleep; morphin } \\
1 / 2 \text { grain given } \\
\text { during the } 6 \\
\text { hours after in- } \\
\text { somnia ended; } \\
\text { rabbit moved } \\
\text { just as if awake } \\
\text { during this time }\end{array}$ & $\begin{array}{c}112 \text { hours } \\
\text { insomnia } \\
\text { and } 6 \\
\text { more } \\
\text { under } \\
\text { morphin }\end{array}$ & $\begin{array}{l}\text { Active......47 } \\
\text { Fatiguod...45 } \\
\text { Exhausted.. } 8\end{array}$ & $\begin{array}{l}\text { Cortex: Most of } \\
\text { the cortex show- } \\
\text { ed loss of cyto- } \\
\text { plasm } \\
\text { Medulla: normal }\end{array}$ & $\begin{array}{l}\text { All cells showed } \\
\text { great or complete. } \\
\text { loss of cyto- } \\
\text { plasm; n u le i } \\
\text { eccentric }\end{array}$ \\
\hline .25 & $\begin{array}{c}\text { Rab- } \\
\text { bit }\end{array}$ & Same as Exp. 24 & $\begin{array}{l}\text { Same as } \\
\text { Exp. } 24\end{array}$ & $\mid \begin{array}{l}\text { Active......55 } \\
\text { Fatigued...38 } \\
\text { Exhausted.. } 7\end{array}$ & $\begin{array}{l}\text { Oortex: Marked } \\
\text { loss of cytoplasm } \\
\text { everywhere } \\
\text { Medulla: stained } \\
\text { poorly }\end{array}$ & $\begin{array}{l}\text { Marked loss of } \\
\text { cytoplasm but } \\
\text { less marked than } \\
\text { in Exp. } 32 \text { (see } \\
\text { Table 5) }\end{array}$ \\
\hline
\end{tabular}

* Glycogen test showed corresponding loss of glycogen. 
Summary of Histologic Findings.-Prolonged insomnia causes demonstrable histologic changes in three organs only: the brain, the liver and the suprarenals.

(a) Brain-Cell Changes Produced by Insomia: 1. Insomnia of more than 100 hours' duration caused histologic changes in all parts of the central nervous system, these changes being most marked in the cortex and cerebellum, but clearly demonstrable also in the medulla and the cord. On account of the comparative ease of application of differential counts of the Purkinje cells, the changes produced in these

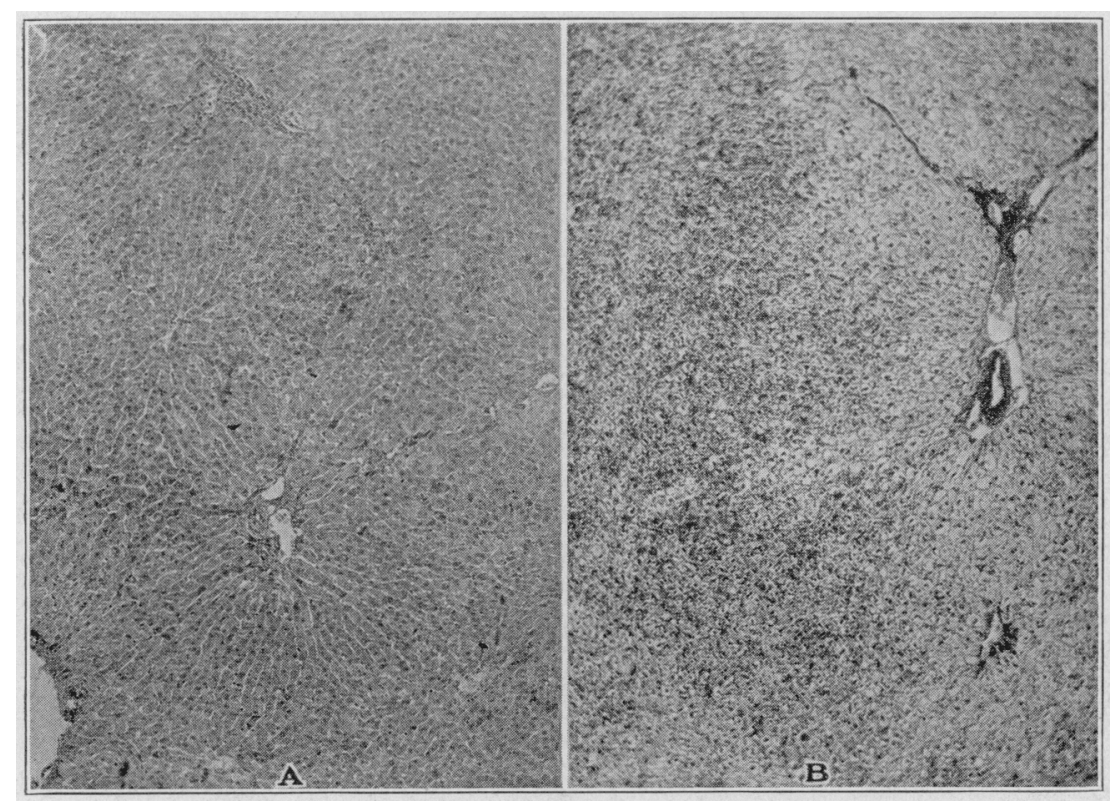

Fig. 5.-Changes in the cells of the liver produced br prolonged insomnia: $A$. section of normal liver of rabbit; $B$, section of liver of rabbit after insomnia of one hundred and nine hours' duration. $\times 100$. The general disappearance of cytoplasm may be noted in $B$.

cells have been taken as an index of the changes in other parts of the central nervous system.

2. The brain-cell changes consisted in chromatolysis; alteration of the nucleoplasm relation; eccentric position of many nuclei: enlargement of many cells with rupture of their cell and nuclear membranes. and disintegration and death of many cells.

3. One seance of sleep restored all the cells except those in which the destructive process had progressed to the disintegration of the nucleus. 
4. In eleven cases in which the animals died apparently as a result of the insomnia alone, differential cell counts demonstrated that 15 per cent. of the cells were exhausted. It would appear, therefore, that life does not continue after approximately 15 per cent. of the brain cells have become fully exhausted.

5. In those animals, which instead of being allowed natural sleep were placed for the same length of time under nitrous oxid-oxygen anesthesia, 90 per cent. of the brain cells became hyperchromatic-a

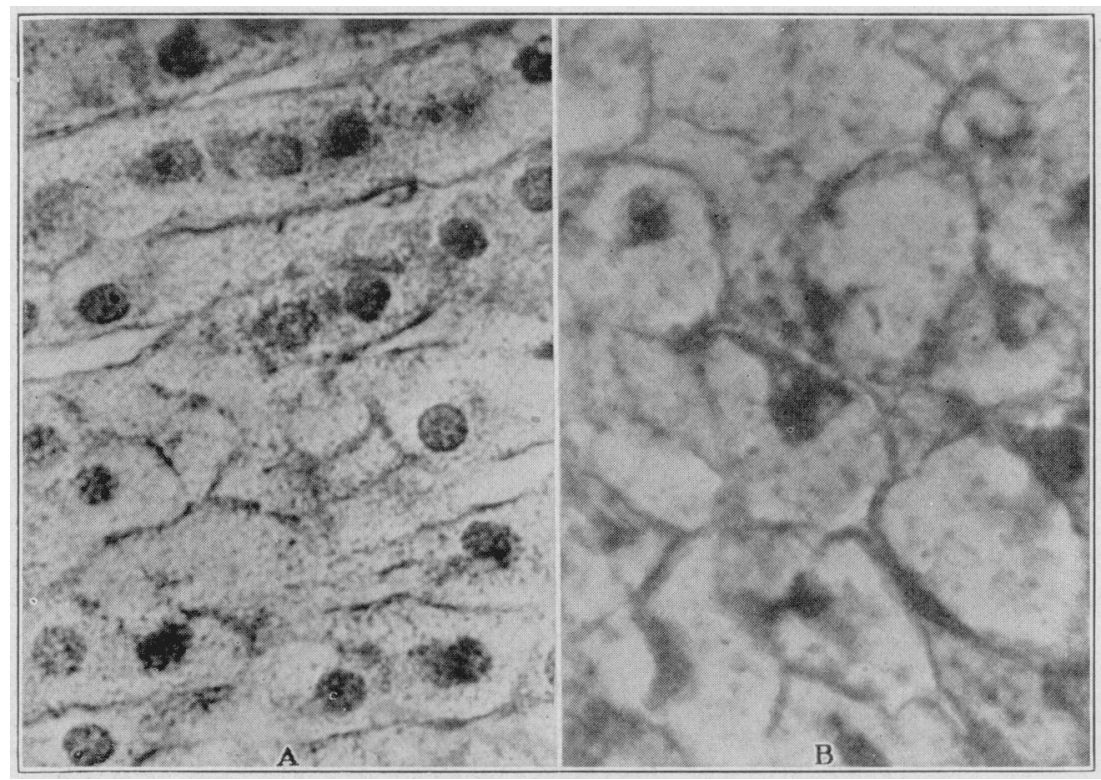

Fig. 6.-Changes in the cells of the liver produced by prolonged insomnia: .4 , section of normal liver of rabbit; $B$, section of liver of rabbit after insomnia of one hundred and nine hours' duration. $\times 1600$. The disappearance of some nuclei in $B$ and the misshapen and eccentric appearance of the rest may be noted.

significant fact, the logical sequence of which will be elaborated elsewhere.

6. Apparently the exhatusted cells are removed by phagocytic action (Fig. 9).

(b). Histologic Changes in the Liver Produced by Insomnia: 1. Insomnia for more than 100 hours caused demonstrable histologic changes in the liver, these changes being most marked near the periphery of the lobules.

2. The cell changes in the liver consisted in the enlargement or swelling of the cells; general disappearance of cytoplasm; the presence 
of racuolated spaces, and the displacement and occasional disappearance of nuclei.

3. Une seance of sleep restored nearly to normal all cells except those in which the nuclei had disappeared.

(c) Histologic Changes in the Suprarenals Produced by Insomnia: 1. Insomnia for more than 100 hours caused demonstrable histologic changes in the suprarenal cortex.

2. The changes in the suprarenal cortex consisted in enlargement of the cells with occasional rupture of the cell wall; distortion of the cell outlines; eccentric displacement of the nuclei which were often crenated, and general disapparance of cytoplasm.

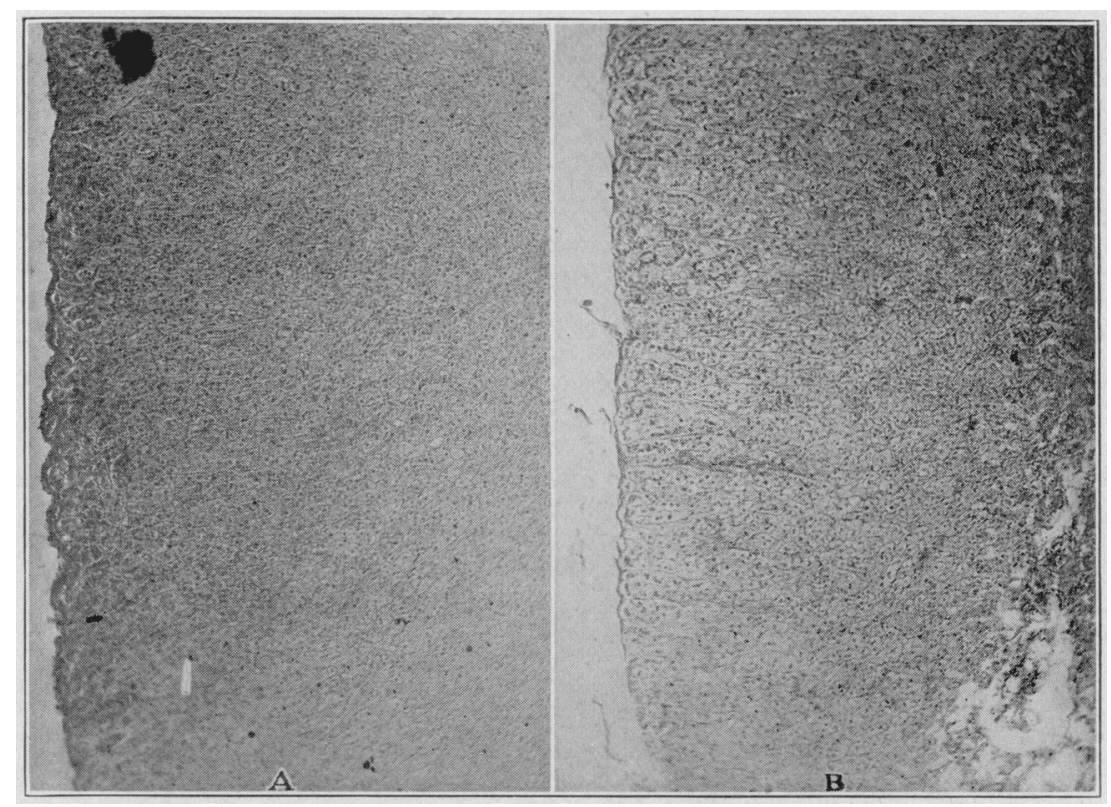

Fig. 7.-Changes in the cells of the suprarenals produced by prolonged insomnia: $A$, section of normal suprarenal of rabbit; $B$, section of suprarenal of rabbit after insomnia of one hundred and nine hours' duration. $\times 100$. The vacuolated spaces and the general disappearance of cytoplasm in $B$ may be noted.

\section{R. PHISICOCHEMICAL STEDIES-IIVIROGEN-ION DETERMINATIONS}

The intravenous injection of acid, such as acid sodium phosphate and hydrochloric acid, causes lesions in the brain, the suprarenals and the liver identical in appearance with the lesions of exhaustion from insomnia, exertion, emotion, infection, etc. Therefore, it seemed advisable to determine whether or not the $\mathrm{H}$-ion concentration is increased by insomnia and whether or not the $\mathrm{H}$-ion concentration is altered by 
sleep. H-ion determinations were, therefore, made in our laboratory by Dr. M. L. Menten, who had worked for a year with Michaelis and used his gas-chain method."

(a) Determinations of the $\mathrm{H}$-ion concentration of the blood of six rabbits, before and after insomnia for ninety-six hours are given in Table 9.

(b) Determinations of the $\mathrm{H}$-ion concentration of the blood of six rabbits after insomnia for one hundred hours followed by sleep for twelve hours are given in Table 10 .

TABle 9.-Hydrogen-Ion Concentration Before and After Insomnia

\begin{tabular}{|c|c|c|c|c|}
\hline \multirow[b]{2}{*}{$\begin{array}{l}\text { Rabbit } 1 \\
\text { Rabbit } 2 \\
\text { Rabbit } 3 \\
\text { Rabbit } 4 \\
\text { Rabbit } 5 \\
\text { Rabbit } 6\end{array}$} & \multicolumn{2}{|c|}{$\begin{array}{l}\text { Before } \\
\text { Insomnia }\end{array}$} & \multicolumn{2}{|c|}{$\begin{array}{l}\text { After } \\
\text { Insomnia }\end{array}$} \\
\hline & $\begin{array}{r}p \mathrm{H}-7.67 \\
7.66 \\
7.61 \\
7.61 \\
7.57 \\
7.64\end{array}$ & $\begin{array}{l}7.66 \\
7.66 \\
7.60 \\
7.61 \\
7.58 \\
7.60\end{array}$ & $\begin{array}{r}p_{\mathrm{H}}-7.62 \\
7.68 \\
7.70 \\
7.65 \\
7.70 \\
7.66\end{array}$ & $\begin{array}{l}7.65 \\
7.68 \\
7.68 \\
7.67 \\
7.70 \\
7.68\end{array}$ \\
\hline Average & 7.63 & 7.62 & 7.67 & 7.68 \\
\hline
\end{tabular}

TABLE 10.-Hydrogen-Ion Concentration After Insomnia for One Hundred Hours Followed by SleEp

\begin{tabular}{|c|c|c|}
\hline 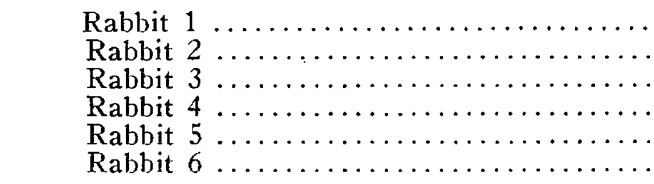 & $\begin{array}{r}p_{\mathrm{x}}-7.66 \\
-7.61 \\
7.66 \\
7.69 \\
7.64 \\
7.64\end{array}$ & $\begin{array}{l}7.67 \\
7.61 \\
7.66 \\
7.64 \\
7.64 \\
7.64\end{array}$ \\
\hline Average .. & 7.65 & 7.64 \\
\hline
\end{tabular}

We may conclude from these studies that prolonged insomnia alone produces relatively slight or no appreciable alteration in the $\mathrm{H}$-ion concentration of the blood.

(c) Determinations of the $\mathrm{H}$-ion concentration during sleep: -While on duty at the American Ambulance in Paris during the first year of the war, we had under our care patients with total cross lesions of the spinal cord. The resultant sensory paralysis 'gave us a long desired opportunity for making $\mathrm{H}$-ion determinations of blood taken from the subject during sleep.

5. Menten, M. L., and Crile, G. W.: Am. J. Physiol. 38:225-232, 1915. Michaelis, Leonor: Einfuhrung in die Farbestoffchemie, Berlin, 1902; Die Wasserstoffionen-konzentration, Berlin, 1914. Crozier, W. J., Rogers, W. B., and Harrison, B. I.: Surg., Gynec. \& Obst. 21:722-727, 1915. 
Tests of blood taken from these patients were made for me by Dr. W. J. Crozier, who found no appreciable difference between the $\mathrm{H}$-ion concentration of the blood taken during sleep and that taken when the patients were awake.

\section{ELECTRIC CONDUCTIVITY MEASUREMENTS}

The histologic changes which our previous researches had shown were characteristic of exhaustion from any cause, in particular the changes in the cells of the brain and of the liver, led us to expect that the electrolyte content of the cells, and consequently their conductivity, must be altered. This supposition was strengthened by the studies of the permeability of living cells which have been made by Osterhout," Galeotti, ${ }^{7}$ Lillie, ${ }^{8}$ Loeb $^{9}$ and others.

TABLE 11.-Changes in the Electric Conductivity of the Brain and Spinal Cord

\begin{tabular}{|c|c|c|c|}
\hline & Cerebrum & Cerebellum & Spinal Cord \\
\hline Average normal conductivity. & 0.00189 & 0.00164 & 0.00180 \\
\hline Average conductivity after insomnia; 96 hours...... & 0.00185 & 0.00149 & 0.00138 \\
\hline Average conductivity after insomnia; 96 hours fol- & & & \\
\hline 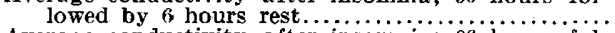 & 0.00183 & 0.00141 & 0.00150 \\
\hline 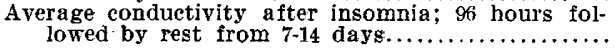 & 0.00203 & 0.00157 & 0.00159 \\
\hline
\end{tabular}

To determine this point, in the spring of 1917 , a research was initiated in collaboration with G. B. Obear of the Case School of Applied Science. The research was interrupted by the war, but was resumed in the fall of 1918, in collaboration with Miss Helen R. Hosmer and Miss Amy F. Rowland.

In this research, we have measured the conductivity of 4,798 sections of various tissues from 436 rabbits and 137 clinical specimens. The tissues have included the cerebrum, the cerebellum, and the liver of every rabbit studied; and in many of them also the spinal fluid, the blood, the suprarenals, the thyroid, the spleen, the pancreas, the kidneys and the voluntary and involuntary (heart) muscle.

After establishing the apparent range of conductivity of these tissues, especially the brain and the liver, in normal animals, under varying

6. Osterhout, W. J. V.: Science 35:112-115, 1912; ibid. 34:187-189, 1911; J. Biol. Chem. 31:585-589, 1917; J. General Physiol. 1:515-519, 1919.

7. Galeotti, G.: Ztschr. f. Biol. 45:65-78, 1904; ibid. 43:289-340, 1902.

8. Lillie, R. S.: Biol. Bull. 33:135-186, 1917; ibid. 17:188-208, 1909; Science 30:245-249, 1909; Am. J. Physiol. 29:372-397, 1912; Am. J. Physiol. 41:126-136, 1916.

9. Loeb, J.: J. Biol. Chem. 27:363-375, 1916; ibid. 28:175-184, 1916; The Organism as a Whole, from a Physico-Chemical Viewpoint, New York, G. P. Putnam's Sons, 1917; Loeb, J., and Bentner, R.: Biochem. Ztschr. 41:1-26, 1912. 
conditions-rarying lengths of confinement, different seasons, etc.groups of rabbits were subjected to exhaustion from various causes: prolonged insomnia, extreme fright, physical trauma (surgical shock), infection, hydrochloric acid injection, thyroid feeding, iodoform poisoning, strychnin poisoning, prolonged ether anesthesia, prolonged nitrous oxid anesthesia. We have observed also the effect on the electric conductivity of the brain and the liver of the inceptive stage of surgical shock, of toxic shock, of strychnin and epinephrin shock. We have observed also the effects of sleep and of rest after prolonged insomnia,

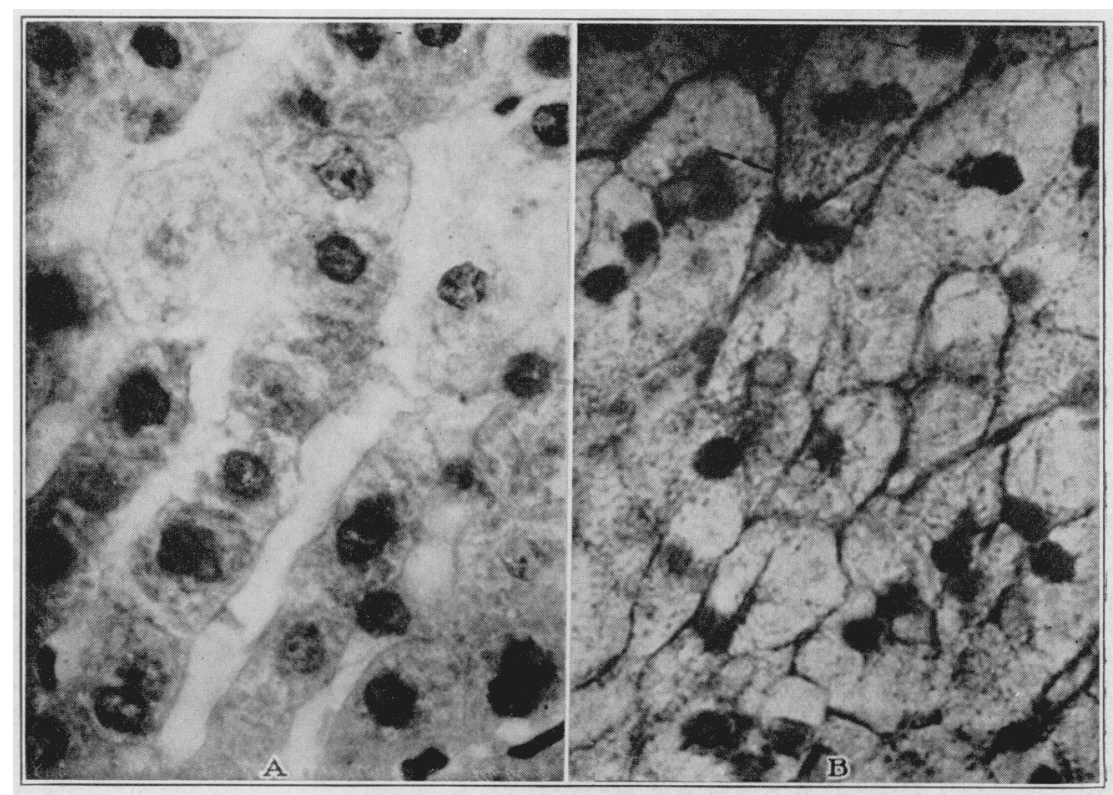

Fig. 8.-Changes in the cells of the suprarenals produced by prolonged insomnia: $A$, section of normal suprarenal of rabbit; $B$, section of suprarenal of rabbit after insomnia of one hundred and nine hours' duration. $\times 1600$. The eccentric and irregularly shaped nuclei and the generally disorganized appearance of the cells in $B$ may be noted.

and of morphin in the presence of infection. We have measured the conductivity of the brain and of the liver in fetuses, in new-born and in young rabbits.

The pathologic tissues measured have included exophthalmic goiters, adenomas, colloid goiters, malignant thyroids, roentgen-ray burns, uterine fibroids, breast cysts and various types of carcinoma and sarcoma.

Our findings in each of these studies will be reported in the appropriate sections of these "Studies in Exhaustion." 
The findings in the studies on insomnia are given in detail in Table 11 and in the charts. The subjoined findings are of especial significance as they parallel the histologic findings:

1. Prolonged insomnia, ninety-six hours, decreased the conductivity of the central nervous system-cerebrum, cerebellum and spinal cord (Fig. 10).

$\therefore$ 2. When prolonged insomnia, ninety-six hours, was followed by a short period of rest, 6 hours, the conductivity of the cerebrum and of the cerebellum was decreased still more than at the close of the

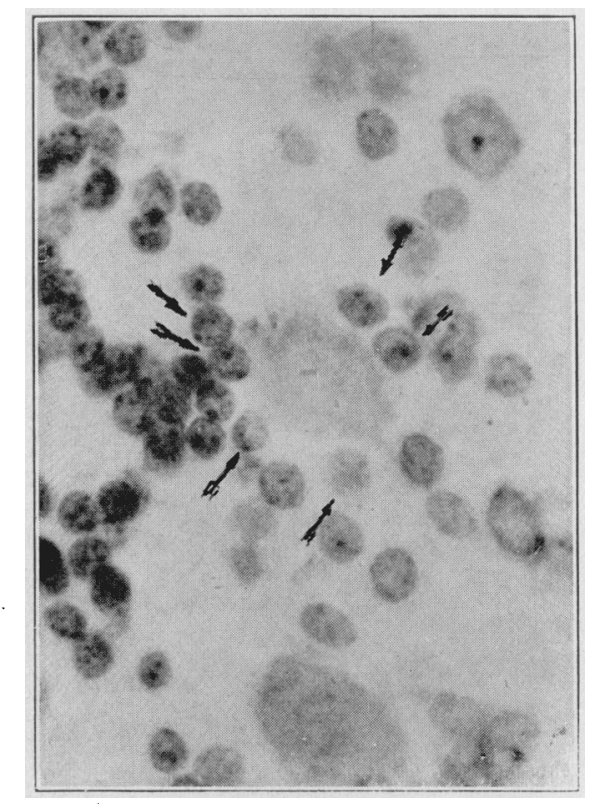

Fig. 9.-Exhausted Purkinje cells surrounded by phagocytes.

insomnia period. The conductivity of the spinal cord began to return toward the normal (Fig. 11).

3. When prolonged insomnia, ninety-six hours, was followed by a prolonged period of rest, from nine days to two weeks, the conductivity of the cerebrum was increased above the normal, and the conductivity of the cerebellum and of the spinal cord approached the normal (Fig. 11).

\section{CLINICAL FINDINGS}

In each experiment at the end of the period of insomnia, every gross clinical sign indicated that the animal was in a condition of extreme exhaustion. 


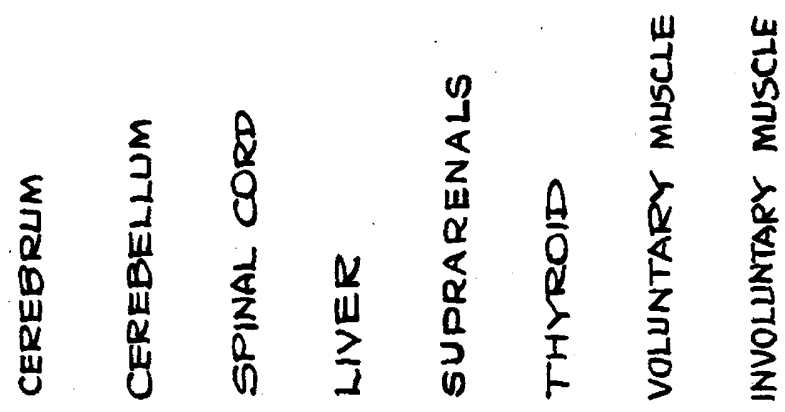

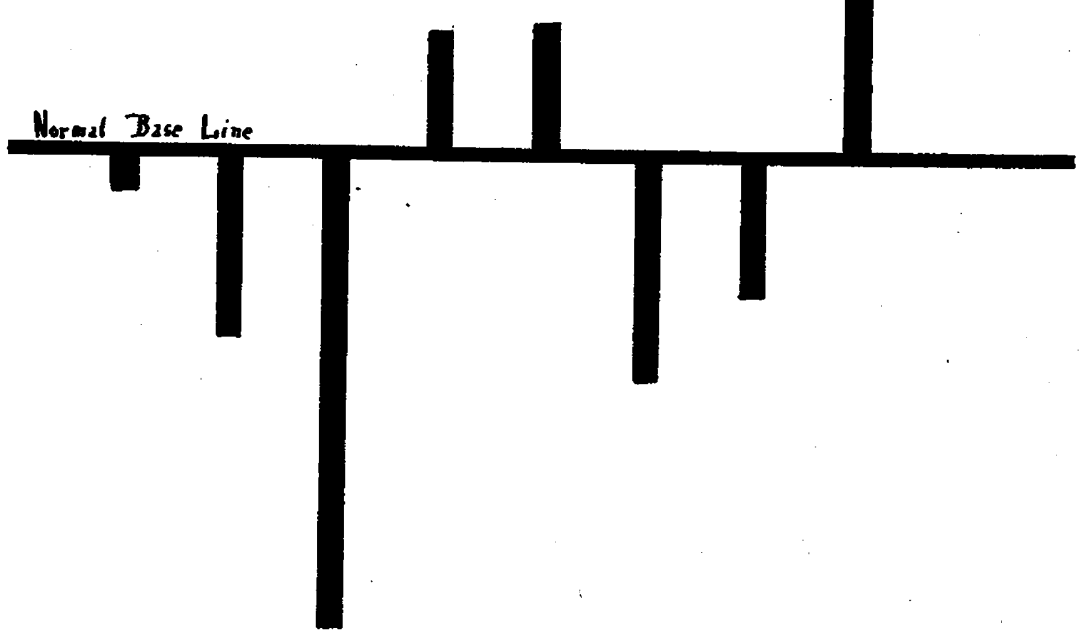

Fig. 10.-Comparative changes above and below the normal in the electric conductivity of various tissues, produced by prolonged insomnia. 
Temperature.- In twenty-two out of forty-two cases, the temperature rose an average of $1.5 \mathrm{~F}$. (minimum 0.2 , maximum 5.3 ) during the period of insomnia. In fourteen cases it fell an average of $0.9 \mathrm{~F}$. (minimum 0.4, maximum 2.0). In the remaining six cases it neither fell nor rose. In general, therefore, the temperature tended to rise. It may again be emphasized here that none of the rabbits selected for these experiments showed any sign of disease before or during the period of insomnia. Apparently, therefore, the increased temperature was purely a work phenomenon.

Respiration.-In six out of forty-two cases, the respiratory rate showed an average increase of 47 per minute (minimum 12, maximum 102) during the period of insomnia. In thirty-one cases, it showed an average decrease of 46 per minute (minimum 11, maximum 129). In five cases it was unchanged.

Weight.-In twenty-three out of forty-two cases, there was an average gain in weight of $107 \mathrm{gm}$. (minimum 5, maximum 588) during the period of insomnia. In eighteen cases, there was an average loss of $107 \mathrm{gm}$. (minimum 2, maximum 432). In one case, the weight was unaltered. The rabbits ate when they wished, having access to food and water all the time, and were weighed at regular intervals. Chance and individual differences were doubtless the chief factors in determining gain or loss in weight.

Urine.-In seventeen cases, the urine was tested for diacetic acid and acetone before and after the insomnia period, but in no case was either found. A few tests for albumin and sugar were negative.

Summary of Experimental Clinical Findings.-(a) Prolonged insomnia as evidenced by these experiments tends to produce a rise in temperature.

(b) The respiratory rate tends to fall during prolonged insomnia. This observation is significant in view of the fact that the $\mathrm{H}$-ion concentration was not increased by insomnia, since increased acidity invariably causes an increased respiratory rate.

(c) No consistent changes in weight were demonstrated by these experiments.

\section{GENERAL SUMMARY}

1. Prolonged insomnia produces histologic lesions in the central nervous system, the liver and the suprarenals.

2. Prolonged insomnia produces no appreciable alteration in the $\mathrm{H}$-ion concentration of the blood.

3. Prolonged insomnia decreases the electric conductivity of the central nervous system-cerebrum, cerebellum and spinal cord. 

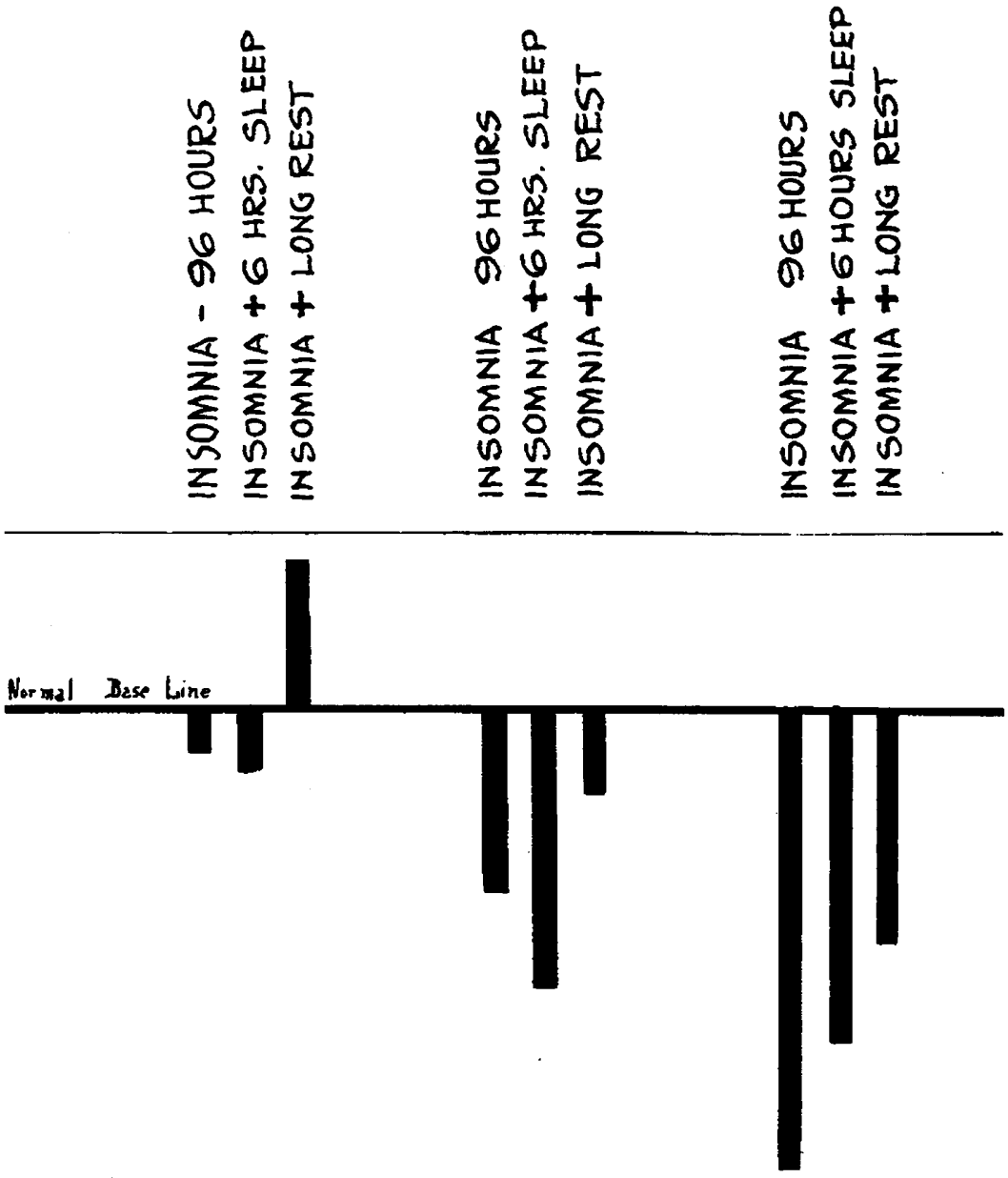

\section{CERERRLM CEREBELLUM SPINAL CORD}

Fig. 11.-Comparison of the variations in electric conductivity of the cerebrum, cerebellum, and the spinal cord produced by insomnia, and by insomnia followed by periods of rest. 
4. Sleep repairs the histologic lesions in the central nervous system and in the liver in all cells except those in which the nucleus has become disintegrated.

5. Sleep and rest, if sufficiently prolonged, increase the electric conductivity of the cells of the central nervous system to, or above, the normal.

6. Nitrous oxid-oxygen to some extent appears to be an efficient substitute of sleep in its restorative effect on the brain cells.

1021 Prospect Avenue. 